VERNON M. BRIGGS, JR.*

\title{
The Strike Insurance Plan of the Railroad Industry
}

A FAR-REACHING program designed to minimize revenue losses during strikes became operative in the nation's railroad industry on September 1, 1959. ${ }^{1}$ The plan is formally known as the Service Interruption Policy, or, more commonly, as the railroad strike insurance plan.

\section{Labor Relations in Railroading}

The government has traditionally assumed a major role in the railroads' product and labor markets. Most operation decisions and rate-setting activities are regulated by the Interstate Commerce Commission and labor-management relations have been the subject of pervasive governmental policies for decades. ${ }^{2}$

Throughout the fifties and early sixties, the industry was in a state of economic listlessness. In an effort to rescue itself from this predicament, railroad management undertook two major policies: consolidation of competing lines and introduction of advanced technology. Both steps led to frequent union-management conflict. Aside from recent product market problems, the bargaining structure of the industry has long proved to be a breeding ground of unrest. Over forty craft unions represent approximately six hundred thousand railroad workers. Most of the unions are quite small and the majority of the members are concentrated in 23 national labor unions. Approximately 25 per cent of unionized employees are in the five operating brotherhoods. In a number of instances, several unions compete for the same members. Multiple and rival unionism have intensified the traditional militancy of the operating crafts and, in addition, have led to

- Assistant Professor of Economics, University of Texas.

1 Brief for plaintiffs, p. 5, W. P. Kennedy v. Long Island R.R., 211 F. Supp. 480 (S.D.N.Y. 1962). The only major railroad that is not currently a member is the New York, New Haven, and Hartford Railroad. Originally a participant, this line was forced to withdraw due to bankrupt status.

2 See Reed C. Richardson, The Locomotive Engineer 1863-1963: A Century of Railway Labor Relations (Ann Arbor: University of Michigan, Bureau of Industrial Relations, 1963), Chap. XV; Jacob J. Kaufman, Collective Bargaining in the Railroad Industry (New York: King's Crown Press, 1954), Chap. V; Edward B. Shils, "Transportation's Labor Crisis," Harvard Business Review, XLII (May, 1964), 84-98. 
a very fragmented bargaining structure and a high degree of strike exposure.

The strike is a particularly potent weapon in this industry. Virtually all passenger service and much of the freight service carried by the railroads cannot be postponed. If service is not provided on time, business is usually lost to other forms of transportation or to nonstruck competitors. Opportunities to increase business prior to a strike or to recoup business lost after a strike are severely limited.

\section{Establishment of the Strike Insurance Program}

The railroad industry has stated that the immediate cause for the developing of the strike insurance proposal was an alleged change in union strike tactics. They contend that "beginning in 1950, there was a shift in the tactics of railroad labor away from the national strike to the selective or 'whipsaw' strike against one or a few of the railroads." In most of these strikes, unions sought settlement terms in excess of those recommended by Presidential Emergency Boards. ${ }^{4}$

The interest of the industry in a mutual assistance agreement was undoubtedly aroused by other factors as well. The year 1959 marked the beginning of the attempt by the railroads to institute revised work rule plans, which were likely to increase strikes. Moreover, the industry claimed to be in a precarious financial position; in 1959 the average rate of return on net invested capital in the industry was only 2.72 per cent. ${ }^{5}$ Many lines were not in a position to sustain a prolonged strike and were quite vulnerable to the whipsaw strike pattern. The railroads were also seeking a counter device to the long-established strike benefit programs of the unions. Furthermore, under an interpretation given to the provisions of the Railroad Un-

${ }^{3}$ Brief for defendant, pp. 59-62, W. P. Kennedy v. Long Island R.R., 211 F. Supp. 480 (S.D.N.Y. 1962).

4 The unions have acknowledged this fact. See Brief for Plaintiffs, p. 45, which states that “... the recommendations of the Emergency Board have been generally unacceptable to labor in recent years."

6 The average figure of 2.72 per cent return on invested capital is somewhat misleading. The financial positions of the respective lines in the industry vary widely. For example, Fortune, August, 1959, p. 129, reported the following rates of return for the 33 largest lines in 1959:

\begin{tabular}{llc}
\hline \hline & $\begin{array}{c}\text { Rate of return on } \\
\text { net invested capital }\end{array}$ & $\begin{array}{c}\text { Number of firms } \\
\text { in category }\end{array}$ \\
\hline Twice average (over 5.4\%) & 9 \\
Between 2.72\% and 5.4\% & 11 \\
Overall average (2.72\%) & 0 \\
Between 0 and 2.72\% & 9 \\
Negative return & 4 \\
\hline
\end{tabular}

Interestingly, the major strikes in the industry have-with few exceptions-been against firms which are consistently returning less than average for the industry. 
employment Insurance Act, primary strikers who have complied with all of the terms of the Railway Labor Act and with the constitution and bylaws of their union are entitled as of the first day of the strike to receive unemployment compensation for up to 130 days. $^{6}$

Accordingly, in May 1959, the Association of American Railroads (AAR) requested the Imperial Insurance Company of Nassau, Bahamas, to write a strike insurance policy. Under the terms of the original policy, a minimum participation figure was established before the plan could become operative. The requirement was that member railroads must account for at least 65 per cent of the gross operating revenues of all railroads within the United States in the preceding year. ${ }^{7}$ The actual response to the program was such that it was overwhelmingly accepted by practically the entire industry. ${ }^{8}$ It became effective on September 1, 1959, for an initial three-year period and has been renewed annually since 1962 .

\section{Provisions of the Plan}

The Service Interruption Policy is administered by a threeman Advisory Committee. Each member is chairman of one of the three regional bodies that comprise the organizational structure of the AAR. The Committee must review the applications of all the railroads which seek to join the plan and certify that the submitted valuation of fixed costs is a reasonable estimate. In the event of a strike, the Committee is required to determine whether or not the strike is covered by the policy.

Under the terms of the policy, a railroad has an indemnifiable work stoppage when the strike (1) is contrary to the provisions of the Railway Labor Act, (2) is to enforce demands contrary to the recommendations of a Presidential Emergency Board, or (3) is in resistance to the application of recommendations of such Emergency Boards. In addition, a strike against a member is covered if the issue involved may affect in the future railroads who represent more than 50 per cent of the aggregate insured railroad indemnities and an Emergency Board has not been appointed or failed to make a definite finding on the issue. ${ }^{9}$

${ }^{6}$ Brotherhood of Railway and Steamship Clerks v. Railroad Retirement Board, 239 F. 2d 43 (C.A.D.C. 1956). For a discussion of this issue see Hearings, Railroad Retirement and Railroad Unemployment Insurance Legislation, U.S. House Committee on Interstate and Foreign Commerce, 85th Cong., Ist sess. (Washington, D.C.: 1957), pp. 434, 463-465, 482-487; and idem., 86th Cong., lst sess. (Washington, D.C.: 1959), pp. 127, 130-131, 172-177.

7 Service Interruption Policy, issued by the Imperial Insurance Company, Ltd., Art. X (1959). In the revised version of 1962, the figure for renewal was lowered to 50 per cent of the gross operating revenue of the industry in the year prior to the anniversary date of the policy. If the participation figure is not attained, the insurance ceases on the expiration date.

8 Press Release by the Association of American Railroads, August 17, 1959. See also Wilbur J. Brons, “Rails Strike Insurance 'Tailor made,", Journal of Commerce, November 5, 1959, p. 10. Service Interruption Policy, Art. III (1962). 
If the Advisory Committee rules that the strike is covered, the struck carrier is entitled to an amount equal to its total fixed costs per day (called the daily indemnity) multiplied by the number of days that the strike continues. ${ }^{10}$ Application must be made separately for each day that coverage is sought. The Committee notifies the insurance company to pay the prescribed daily indemnity to the struck railroad. Payment must be made within 21 days of receipt of the approval notice.

Each participating railroad assumes an obligation for three types of premiums when it subscribes to the insurance plan. The first is known as the "minimum premium" and is payable annually. Totalling $\$ 150,000$ a year, it covers administrative expenses. The amount paid by each participant is based on the ratio that its daily indemnity figure bears to the total daily indemnities of all the participating lines.

The second premium is a single payment made when a particular railroad enters into the agreement. This premium may be called an "escrow premium" and is equal to one day's indemnity of the subscribing railroad. It provides an emergency fund for the insurance company to use in the event that benefits are due a struck line and the third type of premium has not yet been received from a nonstruck participant. In such an event, the assessed amount is deducted from the escrow account of the delinquent member.

The third premium-called the "additional premium"-is by far the most significant. After the Advisory Committee determines that a struck railroad is entitled to benefits, the insurance company obtains the funds to pay the benefits by billing the nonstruck members. The amount that each railroad is charged is equal to its prorated share of the daily indemnity due the struck railroad. If, for example, a company's own daily indemnity is one hundredth of the total indemnities of all participants, it would be required to pay one hundredth of the daily indemnity of the struck line.

The "additional premium" that any one railroad must pay in a given year is subject to one of two limitations, whichever occurs earlier. The first is that the maximum number of days that benefits may be received by a struck carrier in any single work stoppage-or paid by the other policy holdersis 365 days. The second is that the maximum annual liability of any single participant for "minimum" and "additional premiums" is set at 20 times its own daily indemnity.

The occurrence of either of two situations renders the insurance plan void in a particular dispute. First, should the government seize a struck line, no benefits are due. Second, if several railroads whose combined daily indem-

10 The exact items which are classified as "fixed costs" are specified in the Application for Service Interruption Policy, sec. 3. 
nities exceed 50 per cent of the total daily indemnities of all participating lines are struck, no benefits are paid. The theory behind the latter situation is that if such a large number of railroads shut down, federal intervention seems certain. ${ }^{11}$

\section{The Program in the Courts}

When the program became public, the operating brotherhoods collectively denounced its objectives. ${ }^{12}$ Shortly afterward-in July 1960-the first major dispute in which strike insurance was involved occurred when the Brotherhood of Railroad Trainmen (BRT) struck the insured Long Island Rail Road. Subsequently, the BRT instituted legal proceedings over the specific legality of the program.

Union lawyers based their case on the contention that the plan violated three statutes: the Railway Labor Act, the Interstate Commerce Act, and the Sherman Act. Under the Railway Labor Act, it was argued that the strike insurance plan was a per se violation of the duty of the employer to bargain in good faith and that it introduced an element of multi-employer bargaining without the consent of the plaintiffs. Under the Interstate Commerce Act, it was contended that the escrow account constituted an illegal pooling of the revenues of competing carriers. It was asserted that under the Sherman Act the plan represented a unilateral attempt by the railroads to fix the price of labor and therefore constituted an illegal restraint of trade. ${ }^{13}$

The railroads contended that the insurance plan was legal. ${ }^{14}$ With respect to the Railway Labor Act, the railroads claimed that the purposes of the Act were furthered by the strike insurance program. By specific denial of benefits to companies that refuse to accept recommendations tendered by Emergency Boards, implicit encouragement is given to railroad bargainers to accept the recommended terms for settlement. As to the antipooling provi-

\footnotetext{
11 See, "Railroad Strike Insurance Plan explained by Buyers at A.M.A. Meet," National Underwriter, November 13, 1959, p. 1.

12 Press Release No. 49 of the Railway Labor Executives Association, July 27, 1959; see also, John Barry, "Strike Insurance: A Threat to Collective Bargaining," American Federationist, LCVIII (March, 1961). 17-20.

13 The reference to Sherman Act provisions is interesting because it represents a paradox in the development of American labor law. For years unions sought exemption from the antitrust laws of the nation on the basis of the fallacy of comparisons between the operation of the product market and the factor market. Yet, in this case, the contention made by the BRT was that labor is a commodity and that wages and working conditions represent the price of the commodity. Since the strike insurance plan is a concerted activity involving employers who control a major portion of the labor market, the participating employers are able to affect the price of the commodity in a manner in which they would not otherwise be able to do. Consequently, strike insurance is a form of price fixing which is a per se violation of the restraint of trade provisions of sec. 1 of the Sherman Act.

14 Besides the Long Island Rail Road, the suit also included as defendants the Association of American Railroads and 22 other railroads.
} 
sions of the Interstate Commerce Act, the defense pointed out that the relevant section was designed to prohibit a type of anticompetitive activity in the product market of the industry which was "entirely foreign to the facts of this case."15 Finally, concerning the Sherman Act, the railroads cited Section 6 of the Clayton Act that "the labor of a human being is not a commodity or article of commerce."

The railroads claimed also that strike insurance is a legal economic weapon specifically sanctioned by both the Clayton Act and the Norris-LaGuardia Act. The anti-injunction clause of the former states that legal protection is extended to "paying or giving to, or withholding from, any person engaged in such dispute, any strike benefits or other moneys or things of value." And the Norris-LaGuardia Act grants injunctive immunity to numerous activities in the labor relations field, one of which is the "paying or giving to, or withholding from, any person participating in such labor dispute, any strike or unemployment benefits or insurance, or other moneys or things of value."

The District Court dismissed the suit, in general adopting the railroads' position. ${ }^{16}$ The BRT appealed the decision. The Court of Appeals, however, unanimously affirmed the decision of the lower court, holding the union position to be "wholly without merit." ${ }^{\prime 17}$ The Supreme Court denied review. ${ }^{18}$

\section{Some Observations on the Program}

While detailed information concerning the actual effect of the program on labor relations is sparse, some observations are possible. Since its adoption, strike insurance has been paid in the case of several brief strikes against small railroads, but for only three strikes against large lines. (The 25-day strike in 1960 against the Long Island Rail Road; a 12day strike in 1960 against the Pennsylvania Railroad; and a 30-day strike in 1962 against the Chicago and North Western Railroad.) There is no indication that the occurrence or the course of these disputes were altered by the availability of strike insurance. Furthermore, there is no evidence that strike insurance has increased strike incidence in the industry or contributed to any noticeable lengthening of strike duration. The strike pattern of the unions has likewise remained basically unaltered. Thus, the impact to date of this mutual assistance agreement on collective bargaining would appear to be minimal.

The Service Interruption Policy represents a relatively new addition to the arsenal of private economic weaponry used in collective bargaining.

\footnotetext{
15 Brief for Defendant, pp. 97-98.

16 W. P. Kennedy v. Long Island R.R., 211 F. Supp. 480, 487-490 (S.D.N.Y. 1962).

17 W. P. Kennedy v. Long Island R.R., 319 F. 2d 366 (2d Cir. 1963).

18375 U.S. 830 (1963).
} 
With its adoption, the railroad industry became the third major industry to employ such a tactic. Programs that are operationally different but conceptually similar have existed in the newspaper publishing business since the late forties and in the airline industry since 1958 . While mutual strike assistance has been studied by other groups, it has not been widely adopted. ${ }^{19}$

Superficially, it would seem that the introduction of these programs could be explained in terms of countervailing power. Most of the unions in the three industries provide substantial strike benefits during shutdowns. Funds are collected nationally and made available locally for specific disputes. But had the advent of these devices been only a response to the existence of union programs, similar agreements would have presumably sprung up in numerous other industries. Actually, it seems that their evolution has been largely a reaction to a particular set of unstable bargaining characteristics, which may not be duplicated elsewhere.

The most important disruptive factor present in all three industries is multiple unionism, with its enhanced strike potential. In the airline and railroad industries, there is the additional problem of rival unionism, which dims the prospects for stable industrial relations even further.

Another characteristic of the three industries is that they are extremely "time sensitive." Employers cannot stockpile inventories for their customers prior to a strike, and opportunities to recover losses after a settlement are limited. Aside from the fact that substitute services are available from other industries during a strike, the firms within the industry are typically oligopolistic in their regional or franchised markets. In the absence of a mutual assistance device, the basically homogeneous nature of the service provided and the lack of appreciable price differentials between firms means that the customers of a struck firm can frequently switch to a nonstruck competitor. When these considerations are combined with a perceptible rise in fixed costs in recent years and a whipsaw strike pattern, it becomes clear that these unique conditions foster mutual assistance programs, whereas such is not the case in most industries.

With respect to public policy, there is little conceptual difference between the use of strike insurance payments by employer groups and strike benefits by unions. ${ }^{20}$ Under existing legislation, however, the Landrum-Griffin Act

19 It is known that the subject has been explored by officials in Hawaiian sugar, California agriculture, trucking, commercial printing, steel, and the food chain business. Only the first two have actually implemented programs. Both of these agreements are very modest and apparently were desired because of the effect that a strike can have on the perishability of the products.

20 The Public Interest in National Labor Policy, report by the First Labor Study Group (New York: Committee for Economic Development, 1961), pp. 135-136. 
requires that virtually all union financial activities-including strike benefit programs-be subjected to federal scrutiny and public inspection. There is no parallel statutory requirement imposed on employer strike assistance programs. In the case of railroads, the actual impact of the Service Interruption Policy in specific disputes could be more effectively evaluated if the industry was directed by the ICC to submit ex post reports on the benefits provided in each strike. In the airline industry, the Civil Aeronautics Board $(\mathrm{CAB})$ has imposed such a requirement on the participants. The grounds for similar action by the ICC are plentiful. Since many railroads have, until recent years, claimed to be in financial doldrums, the liability that each member railroad assumes when it joins the program-upward to 20 times its own daily indemnity-certainly imperils their solvency.

The courts have ruled that strike insurance in the railroad industry does not violate any existing statute. A similar ruling has been made by the $\mathrm{CAB}$ with respect to the airline program. ${ }^{21}$ The newspaper publishers' agreement has not been challenged and there is little chance that it will be. The railroad decisions, however, are somewhat unique in that the District Court ruled that the Service Interruption Policy is specifically protected by existing labor statutes. On this point, it seems to the writer that the lower court interpreted the word "insurance," as it appears in the Norris-LaGuardia Act, in the broadest possible manner. In examining the actual operation of the plan, it is impossible to find any element of commercial risk. ${ }^{22}$ The insurer cannot lose a single cent. All benefits are paid by assessing the nonstruck lines. The insurer actually is paid solely to perform the administrative task of acting as an intermediary transfer agent. While the terms Service Interruption Policy and strike insurance are used interchangeably, it is questionable whether they are actually synonymous. Nevertheless, the fact remains that the courts have determined that the strike assistance plan does not violate any existing laws.

The existence of a mutual strike assistance program is an outward sign of an extremely insecure bargaining foundation. In the railroad industry, as well as in the airline and newspaper publishing industries, the public interest would be far better served if more attention were focused on the causes of instability and strikes rather than on the symptoms of the trouble.

21 Opinion of the Board (July 10, 1964), CAB Docket No. 9977, Order E-21044. The $\mathrm{CAB}$, however, plans to review its decision in 1967 to see if the agreement has had any adverse effects on collective bargaining in the industry.

${ }^{22}$ See, "Railroad Strike Insurance Plan . . .," p. 1, for a discussion which concurs with my own conclusion. 